\title{
Serum Melatonin Levels in Patients with Sudden Sensorineural Hearing Loss
}

\section{Ani Sensörinöral İşitme Kaybında Serum Melatonin Düzeyleri}

\section{(D) Ahmet BAKì1, iD Ömer Faruk ÖZER², iD Muhammet YILDIZ³, iD Fatmanur KÖKTAŞOĞLU2}

1 Üsküdar State Hospital, Clinic of Otolaryngology, İstanbul, Turkey

2Bezmialem Vakıf University Faculty of Medicine, Department of Biochemistry, İstanbul, Turkey

${ }^{3}$ Antalya Training and Research Hospital, Clinic of Otolaryngology, Antalya, Turkey

\section{ABSTRACT}

Objective: This study aimed to investigate the serum melatonin levels of patients with idiopathic sudden sensorineural hearing loss (ISSNHL).

Methods: This study enrolled 22 patients with ISSNHL and 22 asymptomatic healthy volunteers. The subjects underwent pure tone audiometry and serum melatonin levels were measured.

Results: The patient group was composed of 12 women (mean

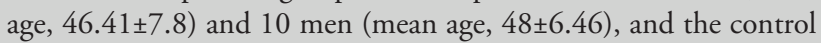
group was composed of 12 women (mean age, $40.25 \pm 5.28$ ) and 10 men (mean age, 38.4 \pm 27.08 ). The serum melatonin levels were significantly lower in the patient group than in the control group $(p \leq 0.001)$. A statistically significant strong negative correlation was found between serum melatonin level and severity of hearing loss $(\mathrm{r}=-0.644 ; \mathrm{p}=0.001)$.

Conclusion: Serum melatonin levels of patients with ISSNHL were lower than controls. A statistically significant strong negative correlation was found between serum melatonin level and the severity of hearing loss.

Keywords: Sudden hearing loss, melatonin, antioxidant

\section{ÖZ}

Amaç: $\mathrm{Bu}$ çalışmanın amacı, idiyopatik ani sensörinöral işitme kaybı (İASİK) olan hastaların serum melatonin düzeylerini ortaya koymaktır.

Yöntemler: İASİK olan 22 hasta ve 22 asemptomatik sağlıklı gönüllü çalışmaya dahil edildi. Katılımcılara saf ses odyometrisi uygulandı ve katılımcıların serum melatonin seviyeleri ölçüldü.

Bulgular: Hasta grubunda 12 kadın [ortalama (ort.) yaş: 46,41 $\pm 7,8$ ] ve 10 erkek (ort. yaş: $48 \pm 6,46$ ) vardı. Kontrol grubunda 12 kadın (ort. yaş: 40,25 $\pm 5,28$ ) ve 10 erkek (ort. yaş: $38,4 \pm 27,08$ ) vardı. Serum melatonin düzeylerinin hasta grubunda kontrol grubuna göre anlamlı derecede düşük olduğu saptandı ( $\leq \leq 0,001)$. Serum melatonin seviyesi ile işitme kaybının şiddeti arasında istatistiksel olarak anlamlı güçlü negatif bir korelasyon vardı $(\mathrm{r}=-0,644$; $\mathrm{p}=0,001$ ).

Sonuç: İASİK olan hastaların serum melatonin düzeyleri kontrol grubundan daha düşüktü. Serum melatonin seviyesi ile işitme kaybının şiddeti arasında istatistiksel olarak anlamlı güçlü negatif bir korelasyon vard.

Anahtar Sözcükler: Ani işitme kaybı, melatonin, antioksidan

Address for Correspondence: Ahmet BAKi, Üsküdar State Hospital, Clinic of Otolaryngology, İstanbul, Turkey

E-mail: dr.ahmet170@gmail.com ORCID ID: orcid.org/0000-0003-2851-0849 


\section{Introduction}

The etiology of sudden hearing loss is only known in $10 \%$ of the cases, and it is still classified as idiopathic in $90 \%$ of the cases. Although idiopathic sudden sensorineural hearing loss (ISSNHL) is an otologic emergency, its etiopathogenesis is not known exactly. Although some theories attempt to explain the pathogenesis of ISSNHL, such as viral infections, membrane rupture, immune-mediated inner ear disease, vascular events, genetic and acquired factors, none of these theories have yet been proven (1).

Hair cells are high-energy and oxygen-consuming cells, and the most important factor for this is the mitochondrial electron transport chain. Reactive oxygen species (ROS), which appears as a result of mitochondrial changes during hypoxia, can trigger cell death by damaging lipids, proteins and deoxyribonucleic acid (2).

ROS causes apoptosis by damaging the inner hair cells. This hypothesis has been verified by showing ROS in the perilymphatic fluid of the inner ear of patients with deep sensorineural hearing loss throughout cochlear implantation surgery (3). Many studies have demonstrated that ROS is linked to many diseases that may cause hearing loss, including noise, drug use, genetic hearing loss, presbycusis, and Meniere syndrome (4-7).

Melatonin is a hormone secreted by the pineal gland, has a direct antioxidant effect, is a potent scavenger of ROS and enhances the activity of antioxidant enzymes (8).

Melatonin is also detected in the organ of Corti, basilar membrane, spiral ligament, stria vascularis and cochlear nerve (9). Lasisi and Fehintala (10) had shown that low plasma melatonin level is important in the development of age-related high-frequency hearing loss.

In this study, we aimed to investigate the serum melatonin levels in patients with ISSNHL to determine whether serum melatonin levels have an effect on the pathophysiology of ISSNHL.

\section{Methods}

\section{Study Population}

The study was planned with 31 patients diagnosed with ISSNHL and 22 healthy volunteers in Uskudar State Hospital Otolaryngology Clinic. The diagnosis of ISSNHL was made according to criteria of the American Academy of OtolaryngologyHead and Neck Surgery (11). Patients with conductive hearing loss, a history of otologic surgery, head trauma, or barotrauma during the previous 4 weeks, neurologic disorders predisposing to hearing loss, accompanying upper respiratory tract infection, autoimmune diseases, vestibular symptoms, fluctuating hearing loss in the last 4 weeks and hearing loss due to pathological brain mass in magnetic resonance imaging were excluded from the study. Following patient screening, nine patients were excluded from the study. The study included 22 patients diagnosed with ISSNHL. The control group was composed of 22 healthy volunteers, i.e. had no ear problems and no chronic systemic disease. Complete history taking, physical examination, laboratory workup, bleeding profile, venereal diseases research laboratory test and antinuclear antibody test were performed in both groups. None of the subjects were taking any antioxidant vitamins.

The study was approved by the ethics committee of Zeynep Kamil Women's and Children's Diseases Training and Research Hospital (Protocol number: 109, date: 27.06.2018).

\section{Audiological Evaluation}

All patients were tested for pure tone audiometry for both ears up to $8000 \mathrm{~Hz}$ frequency starting at $250 \mathrm{~Hz}$ frequency by international standards. Pure-tone average was determined by calculating the mean of the 500,1000, 2000 and $4000 \mathrm{~Hz}$ thresholds. All patients underwent a tympanogram test. Hearing impairment was assessed according to the international standard criteria defined by the World Health Organization Prevention of Deafness and Hearing Impairment standard 97.3 (12).

\section{Laboratory Study}

The human melatonin levels were measured with a competitive enzyme-linked immunosorbent assay (ELISA) using commercial kits (Elabscience; lot no. QQQB5LYL, PRC) and an ELISA reader (Multiskan FC $^{\ominus}$ Microplate Photometer; Thermo Scientific, USA).

In this study, 96-well ELISA plates precoated with anti-human melatonin antibodies were used. The standards and samples were added to the micro ELISA plate wells for binding to the specific antibody. Then, biotinylated detection antibody was added immediately. During the reaction, human melatonin in the sample or standards compete for binding with human melatonin antibody. After a specific incubation period, excess conjugate and independent sample or standards were washed from the plate, and avidin that conjugated to horseradish peroxidase was annexed to every well and incubated. After these procedures, a tetramethylbenzidine substrate solution was supplemented to each well. The enzyme-substrate reaction was finished by the supplement of a stop solution, and the colour shift was measured spectrophotometrically at a wavelength of $450 \mathrm{~nm}$. The human melatonin concentrations in the samples were calculated according to the optical density (OD) in the standard curve and then determined by comparing the $\mathrm{OD}$ of the samples to the classical curve. The results were demonstrated using the $\mathrm{pg} /$ $\mathrm{mL}$ unit. For sensitivity levels, the minimum definable dose of melatonin was $9.38 \mathrm{pg} / \mathrm{mL}$, and the detection range was 15.63 $1000 \mathrm{pg} / \mathrm{mL}$.

\section{Statistical Analysis}

In this study, IBM SPSS Statistics version 22 was used for statistical analysis. Shapiro-Wilk test was used to evaluate the normal distribution of the parameters. Descriptive statistical methods (mean, standard deviations and median value) were calculated. Mann-Whitney U test was used to compare nonparametric data between groups. Spearman correlation test was used to determine the correlation of nonparametric data between two groups. The $r$ value was evaluated between -1 and +1 . Significance was assessed at $\mathrm{p}<0.05$ level. 


\section{Results}

This study enrolled 22 patients with ISSNHL and 22 asymptomatic healthy volunteers. The patient group was composed of 12 women and 10 men. The female patients were $32-62$ years old (mean age, $46.41 \pm 7.80$ years). The male patients were $38-55$ years old (mean age, $48 \pm 6.46$ years). The control group was composed of 12 women and 10 men. The female volunteers were $30-48$ years old (mean age, $40.25 \pm 5.28$ years). The male volunteers were $27-47$ years old (mean age, $38.4 \pm 27.08$ years) (Table 1 ).

Type A tympanogram was obtained in both groups. In the pure tone audiometry test, the mean values of the right air, right bone, left air and left bone were $34.36 \pm 21.66 \mathrm{~dB}, 29.40 \pm 20.88 \mathrm{~dB}$, $40.72 \pm 30.33 \mathrm{~dB}$ and $35.09 \pm 27.77 \mathrm{~dB}$, respectively (Table 1 ). The serum melatonin level averages of the patients and controls were $51.32 \pm 12.45$ and $78.79 \pm 29.39 \mathrm{pg} / \mathrm{mL}$, respectively. The serum melatonin levels were significantly lower in the patient group than in the control group $(\mathrm{p} \leq 0.001)$ (Table 2$)$.

A statistically significant strong negative correlation was found between serum melatonin and severity of hearing loss in the patient group $(\mathrm{r}=-0.644 ; \mathrm{p}=0.001)$. The coefficient of determination $\left(\mathrm{r}^{2}\right)$ between these two variables was 0.232 (Table 3) (Graphic 1).

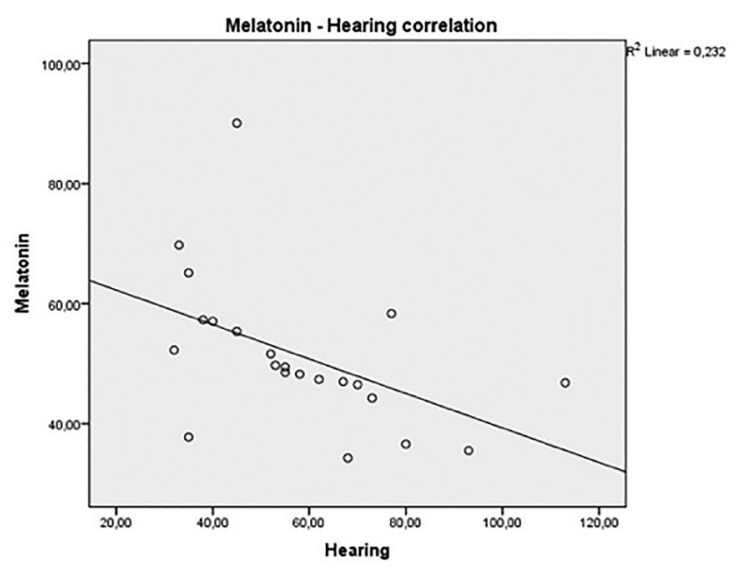

Graphic 1. Correlation between melatonin and hearing level (strong negative correlation is present)

\section{Table 1. Demographic data of the patient and control group}

\begin{tabular}{l|l|l|l|}
\hline Patient group & $\mathrm{N}$ & Min - Max & Mean \pm SD \\
\hline Female age & 12 & $32-62$ & $46.41 \pm 7.80$ \\
\hline Male age & 10 & $38-55$ & $48 \pm 6.46$ \\
\hline Right air & 22 & $7-77 \mathrm{~dB}$ & $34.36 \pm 21.66 \mathrm{~dB}$ \\
\hline Right bone & 22 & $3-70 \mathrm{~dB}$ & $29.40 \pm 20.88 \mathrm{~dB}$ \\
\hline Left air & 22 & $10-113 \mathrm{~dB}$ & $40.72 \pm 30.33 \mathrm{~dB}$ \\
\hline Left bone & 22 & $8-100 \mathrm{~dB}$ & $35.09 \pm 27.77 \mathrm{~dB}$ \\
\hline Control group & $\mathrm{N}$ & Min - Max & Mean $\pm \mathrm{SD}$ \\
\hline Female age & 12 & $30-48$ & $40.25 \pm 5.28$ \\
\hline Male age & 10 & $27-47$ & $38.4 \pm 27.08$ \\
\hline Right air & 22 & $3-20 \mathrm{~dB}$ & $12.59 \pm 5.01 \mathrm{~dB}$ \\
\hline Right bone & 22 & $2-20 \mathrm{~dB}$ & $9.86 \pm 4.27 \mathrm{~dB}$ \\
\hline Left air & 22 & $2-20 \mathrm{~dB}$ & $13.31 \pm 5.42 \mathrm{~dB}$ \\
\hline Left bone & 22 & $2-17 \mathrm{~dB}$ & $9.77 \pm 4.51 \mathrm{~dB}$ \\
\hline
\end{tabular}

dB: Decibel, N: Number of patients, SD: Standard deviation, min: Minimum, max: Maximum

Table 2. Comparison of the serum melatonin levels between the patient group and control group

\begin{tabular}{|c|c|c|c|c|c|}
\hline & $N$ & Min & Max & Mean \pm SD & $p$ \\
\hline
\end{tabular}

Table 3. Correlation between serum melatonin levels and hearing loss levels in the patient group

\begin{tabular}{|c|c|c|c|c|c|c|c|}
\hline & $\mathrm{N}$ & Min & Max & Mean \pm SD & $\mathrm{p}$ & $r$ & $r^{2}$ \\
\hline
\end{tabular}




\section{Discussion}

The pathogenesis of ISSNHL can not be clearly identified because histopathological examination was not possible. Its causes include viral infections, autoimmune inner ear diseases, cochlear vascular pathologies or a combination of these mechanisms $(13,14)$.

Merchant et al. (15) demonstrated that ISSNHL may be the result of the abnormal activation of cellular stress pathways within the cochlea and that nuclear factor kappa B (NF-kB) induces oxidative stress, inflammatory cytokines and other stress-related proteins. This hypothesis was supported by the pathological activation of NF-kB, which stimulated the production of inflammatory cytokines and other proteins due to oxidative stress since the cochlear microcirculation is very sensitive to changes in blood flow velocity, and dysfunction of the cortical organ occurs very quickly even in limited perfusion disorders (16).

Different models of experimentally induced reperfusion injury confirm that free radicals originating from oxygen play a significant role. Clerici and Yang (17) found high-frequency compound action potential threshold shifts in an animal study examining the specific effects of ROS production on cochlear function. Bielefeld et al. (18) found similar findings in a study evaluating the effect of superoxides on inferior colliculus-induced potential thresholds and hair cell damage. In a study comparing the ROS and total antioxidant status (TAS) concentrations on the effect of oxidative stress on ISSNHL, ROS levels were considerably higher in the patient group than in the healthy group, while no significant difference was found between the TAS levels (19).

Dysfunction of endothelial cells leads to an increase in ROS and may result in apoptosis or sudden death of endothelial cells (20). Guo et al. (21) showed that the increase in superoxide radicals and decreased endothelial nitric oxide synthetase activity caused hair cell loss, thickening of the vascular intima and luminal stenosis in the spiral modiolus. Haubner et al. (22) also showed increased adhesion molecules in the vascular circulation of patients with ISSNHL. These studies found that endothelial dysfunction leads to impaired labyrinth perfusion and hearing loss in patients with ISSNHL, indicating the presence of vascular pathology in the etiopathogenesis of the disease.

Melatonin, a pineal secretory product of vertebrates, can be produce in many tissues and cells such as the cochlea $(23,24)$. Melatonin has a neuroendocrinoimmunological role at the tissue level. It has both indirect antioxidant and direct free radical scavenger activity (24). Melatonin ensures these effects by transforming its metabolites, such as cyclic N-1-acetyl-5methoxy kynuramine, 3-hydroxymelatonin and N-1-acetyl-N2formyl-5-methoxykynuramine (25-27). All these metabolites neutralise free radicals. Moreover, studies demonstrated that melatonin induced several antioxidative enzymes, such as glutathione peroxidase, glutathione transferase and superoxide dismutase (28-32).

Melatonin has also been deliberated as a potent antihypertensive treatment. It may also enhance endothelial function by increasing the presence of nitric oxide, thereby exerting vasodilatory and hypotensive effects. Furthermore, it appears to be effective in disorders of the peripheral and central autonomic system by causing a decrease in the function of the adrenergic system and an increase in the cholinergic system (33). Melatonin application reduces the mean pulsatility sign of the internal carotid artery, systolic and diastolic blood pressure and norepinephrine levels (34). It also reduces blood pressure and decreases the catecholamine level in human subjects (35).

A study observed that aminoglycoside ototoxicity improved within 2 weeks, but when melatonin was added, it decreased to 5 days in rats (36). Melatonin as an antioxidant and immune modulator can be also used to treat cisplatin ototoxicity by transtympanic local administration in lower doses (37). Another study showed that free oxygen radicals are effective in the treatment of cochlear damage caused by noise, and melatonin plays a strong role in the protection of cochlear damage (38).

In this study, we investigated the relationship between serum melatonin levels and ISSNHL by taking into account the presence of antioxidant property, direct free radical scavenging activity and antihypertensive property of melatonin. In this study, we found that melatonin levels were significantly lower in patients with ISSNHL than in the control group, and a statistically significant result was obtained. Moreover, a statistically significant strong negative correlation was found between serum melatonin level and the severity of hearing loss.

The results of this study were limited by the small sample size. Nevertheless, we think that the study findings will help in the development of future treatment methods for ISSNHL.

\section{Conclusion}

This study indicates that low serum melatonin levels may be associated with ISSNHL. Serum melatonin levels of patients with ISSNHL were lower than controls. A larger series of studies are required to elaborate on this relationship.

\section{Ethics}

Ethics Committee Approval: The study was approved by the ethics committee of Zeynep Kamil Women's and Children's Diseases Training and Research Hospital (Protocol number: 109, date: 27.06.2018).

Informed Consent: Written informed consent was obtained from the patients.

Peer-review: Internally and externally peer reviewed.

\section{Authorship Contributions}

Surgical and Medical Practices: A.B., Ö.F.Ö., Concept: A.B., Ö.F.Ö., M.Y., Design: A.B., Ö.F.Ö., M.Y., Data Collection or Processing: A.B., Ö.F.Ö., M.Y., F.K., Analysis or Interpretation: A.B., M.Y., F.K., Literature Search: A.B., Writing: A.B.

Conflict of Interest: No conflict of interest was declared by the authors.

Financial Disclosure: The authors declared that this study received no financial support. 


\section{References}

1. Gul F, Muderris T, Yalciner G, Sevil E, Bercin S, Ergin M, et al. A comprehensive study of oxidative stress in sudden hearing loss. Eur Arch Otorhinolaryngol 2017;274:1301-8.

2. Henderson D, McFadden SL, Liu CC, Hight N, Zheng XY. The role of antioxidants in protection from impulse noise. Ann N Y Acad Sci 1999;884:368-80.

3. Ciorba A, Gasparini P, Chicca M, Pinamonti S, Martini A. Reactive oxygen species in human inner ear perilymph. Acta Otolaryngol 2010;130:240-6.

4. Henderson D, Bielefeld EC, Harris $\mathrm{KC}, \mathrm{Hu} \mathrm{BH}$. The role of oxidative stress in noise-induced hearing loss. Ear Hear 2006;27:1-19.

5. Becatti M, Marcucci R, Mannucci A, Gori AM, Giusti B, Sofi F, et al. Erythrocyte Membrane Fluidity Alterations in Sudden Sensorineural Hearing Loss Patients: The Role of Oxidative Stress. Thromb Haemost 2017;117:2334-45.

6. Teranishi M, Uchida Y, Nishio N, Kato K, Otake H, Yoshida T, et al. Polymorphisms in genes involved in oxidative stress response in patients with sudden sensorineural hearing loss and Ménière's disease in a Japanese population. DNA Cell Biol 2012;31:1555-62.

7. Jamesdaniel S, Rosati R, Westrick J, Ruden DM. Chronic lead exposure induces cochlear oxidative stress and potentiates noiseinduced hearing loss. Toxicol Lett 2018;292:175-80.

8. Reiter RJ. Functional aspects of the pineal hormone melatonin in combating cell and tissue damage induced by free radicals. Eur J Endocrinol 1996;134:412-20.

9. Biesalski HK, Welker HA, Thalmann R, Vollrath L. Melatonin and other serotonin derivatives in the guinea pig membranous cochlea. Neurosci Lett 1998;91:41-6.

10. Lasisi AO, Fehintola FA. Correlation between plasma levels of radical scavengers and hearing threshold among elderly subjects with agerelated hearing loss. Acta Otolaryngol 2011;131:1160-4.

11. Stachler RJ, Chandrasekhar SS, Archer SM, Rosenfeld RM, Schwartz SR, Barrs DM, et al. Clinical practice guideline: sudden hearing loss. Otolaryngol Head Neck Surg 2012;146(3 Suppl):1-35.

12. World Health Organization. WHO Ear and Hearing Disorders Survey Protocol for a Population-Based Survey of Prevalence and Causes of Deafness and Hearing Impairment and Other Ear Disorders. Geneva, Switzerland: World Health Organization, 1999.

13. Li G, You D, Ma J, Li W, Li H, Sun S. The Role of Autoimmunity in the Pathogenesis of Sudden Sensorineural Hearing Loss. Neural Plast 2018;2018:7691473.

14. Shi WY, Li KJ, Li Q. Analysis of risk factors for recurrent sudden sensorineural hearing loss. Lin Chung Er Bi Yan Hou Tou Jing Wai Ke Za Zhi 2018;32:976-8.

15. Merchant SN, Durand ML, Adams JC. Sudden deafness: is it viral? ORL J Otorhinolaryngol Relat Spec 2008;70:52-60.

16. Miller JM, Ren TY, Nuttall AL. Studies of inner ear blood flow in animals and human beings. Otolaryngol Head Neck Surg 1995;112:101-13.

17. Clerici WJ, Yang L. Direct effects of intraperilymphatic reactive oxygen species generation on cochlear function. Hear Res 1996;101:14-22.
18. Bielefeld EC, $\mathrm{Hu} \mathrm{BH}$, Harris KC, Henderson D. Damage and threshold shift resulting from cochlear exposure to paraquatgenerated superoxide. Hear Res 2005;207:35-42.

19. Capaccio P, Pignataro L, Gaini LM, Sigismund PE, Novembrino C, De Giuseppe R, et al. Unbalanced oxidative status in idiopathic sudden sensorineural hearing loss. Eur Arch Otorhinolaryngol 2012;269:449-53.

20. Pober JS, Min W, Bradley JR. Mechanisms of endothelial dysfunction, injury, and death. Annu Rev Pathol 2009;4:71-95.

21. Guo Y, Zhang C, Du X, Nair U, Yoo TJ. Morphological and functional alterations of the cochlea in apolipoprotein $\mathrm{E}$ genedeficient mice. Hear Res 2005;208:54-67.

22. Haubner F, Martin L, Steffens T, Strutz J, Kleinjung T. The role of soluble adhesion molecules and cytokines in sudden sensorineural hearing loss. Otolaryngol Head Neck Surg 2011;144:575-80.

23. Lopez-Gonzalez MA, Calvo JR, Rubio A, Goberna R, Guerrero JM. Characterization of melatonin binding sites in the Harderian gland and median eminence of the rat. Life Sci 1991;48:1165-71.

24. Tan DX, Chen LD, Poeggeler B, Manchester LC, Reiter RJ. Melatonin: A potent endogenous hydroxyl radical scavenger. Endocr J 1993;1:57-60.

25. Tan DX, Manchester LC, Reiter RJ, Plummer BF, Hardies LJ, Weintraub ST, et al. A novel melatonin metabolite, cyclic 3-hydroxymelatonin: a biomarker of in vivo hydroxyl radical generation. Biochem Biophys Res Commun 1998;253:614-20.

26. Tan DX, Manchester LC, Burkhardt S, Sainz RM, Mayo JC, Kohen $\mathrm{R}$, et al. N1-acetyl-N2-formyl-5-methoxykynuramine, a biogenic amine and melatonin metabolite, functions as a potent antioxidant. FASEB J 2001;15:2294-6.

27. Ressmeyer AR, Mayo JC, Zelosko V, Sáinz RM, Tan DX, Poeggeler $B$, et al. Antioxidant properties of the melatonin metabolite N1acetyl-5-methoxykynuramine (AMK): scavenging of free radicals and prevention of protein destruction. Redox Rep 2003;8:205-13.

28. Aksoy N, Vural H, Sabuncu T, Aksoy S. Effects of melatonin on oxidative-antioxidative status of tissues in streptozotocin-induced diabetic rats. Cell Biochem Funct 2003;21:121-5.

29. Anwar MM, Meki AR, Rahma HH. Inhibitory effects of melatonin on vascular reactivity: possible role of vasoactive mediators. Comp Biochem Physiol C Toxicol Pharmacol 2001;130:357-67.

30. Benot S, Molinero P, Soutto M, Goberna R, Guerrero JM. Circadian variations in the rat serum total antioxidant status: correlation with melatonin levels. J Pineal Res 1998;25:1-4.

31. Morrey KM, McLachlan JA, Serkin CD, Bakouche O. Activation of human monocytes by the pineal hormone melatonin. J Immunol 1994;153:2671-80.

32. Reiter RJ, Tan DX, Cabrera J, D’Arpa D, Sainz RM, Mayo JC, et al. The oxidant/antioxidant network: role of melatonin. Biol Signals Recept 1999;8:56-63.

33. Simko F, Paulis L. Melatonin as a potential anti-hypertensive treatment. J Pineal Res 2007;42:319-22.

34. Cagnacci A, Arangino S, Angiolucci M, Maschio E, Melis GB. Influences of melatonin administration on the circulation of women. Am J Physiol 1998;274:335-8. 
35. Sewerynek E. Melatonin and the cardiovascular system. Neuro Endocrinol Lett 2002;23(Suppl 1):79-83.

36. Lopez-Gonzalez MA, Guerrero JM, Torronteras R, Osuna C, Delgado F. Ototoxicity caused by aminoglycosides is ameliorated by melatonin without interfering with the antibiotic capacity of the drugs. J Pineal Res 2000;28:26-33.
37. Demir MG, Altıntoprak N, Aydın S, Kösemihal E, Başak K. Effect of Transtympanic Injection of Melatonin on Cisplatin-Induced Ototoxicity. J Int Adv Otol 2015;11:202-6.

38. Karlidağ T, Yalçin S, Oztürk A, Ustündağ B, Gök U, Kaygusuz I, et al. The role of free oxygen radicals innoise-induced hearing loss: effects of melatonin and methylprednisolone. Auris Nasus Larynx 2002;29:147-52. 